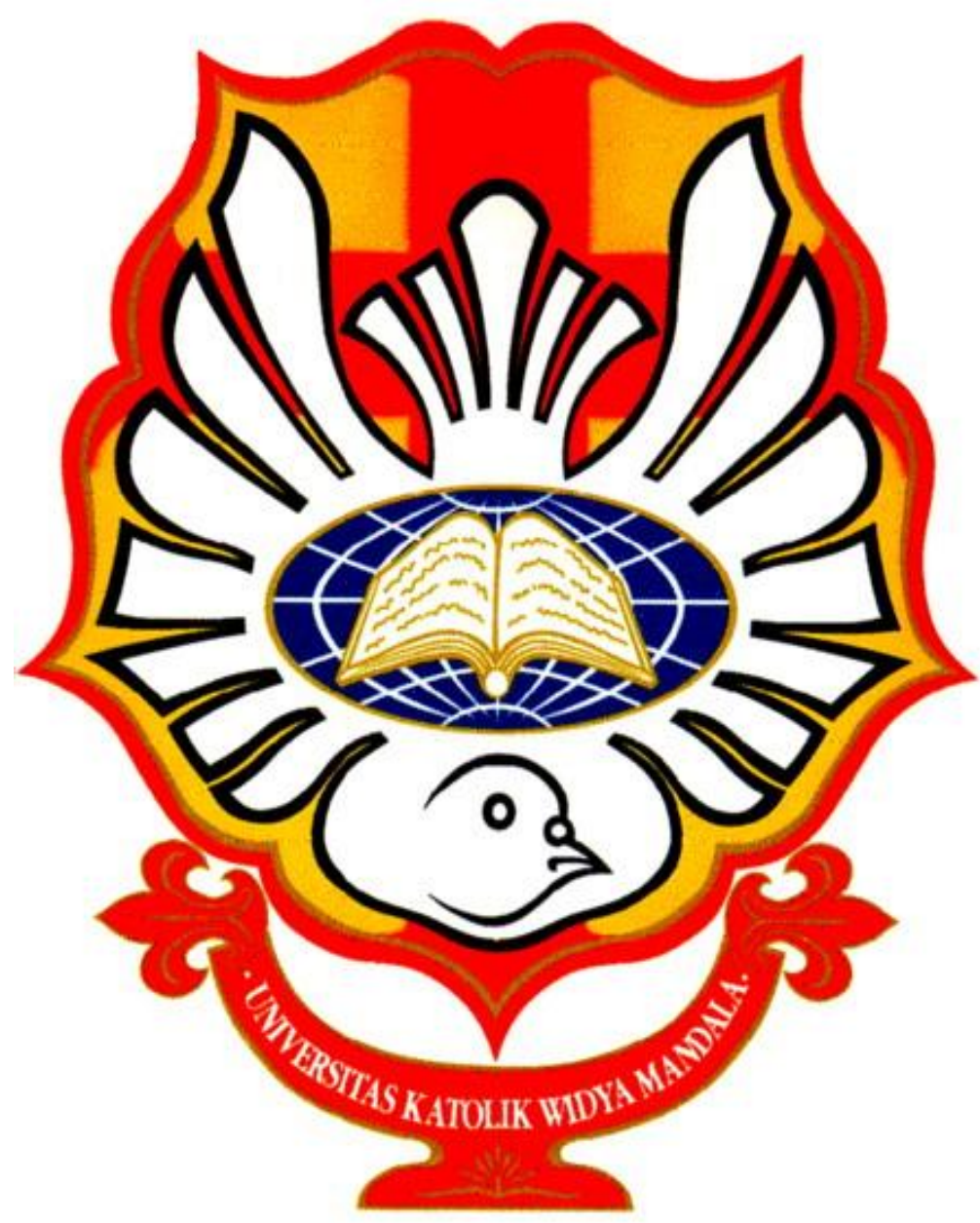

DISUSUN OLEH :

NAMA : DEXTRA HARY PEMUDA WARDANA

NIM : 32318008

PRODI : FARMASI REGULER PAGI 


\title{
DEMOKRASI YANG TERJADI DI INDONESIA DEWASA INI
}

\begin{abstract}
ABSTRAK:
Sistem Negara yang digunakan oleh Negara Indonesia saat ini adalah sistem Demokrasi Pancasila,berdasarkan tokoh-tokoh pendiri bangsa mengapa dipilih Demokrasi Pancasila adalah bahwa Pancasila sudah menjadi budaya bangsa sejak nenek moyang yang di tulis oleh Mpu Pranpanca dalam bukunya Negara kertagama dan Mpu Tantular dalam bukunya Sutasoma di dalam buku tersebut yang di tulis pada zaman kerajaan Majapahit terdapat poin-poin yang itu merupakan sumber dari dasar terbentuknya Negara ini sudah di jelaskan poin-poin dan juga sudah di singgung tentang pancasila di dalam buku tersebut,dan poin yang paling mengena di pribadi masyarakat Indonesia adalah sikap gotong royong dan musyawarah sehingga para pendiri bangsa mendasarkan poin dari pancasila itu sebagai dasar Negara.
\end{abstract}

Kayword:Demokrasi pancasila yang telah memudar,Praktik bersaing untuk menang dalam pemilu saat ini,Imbas cara berkampanye yang menggunakan praktik money politik

\section{DEMOKRASI PANCASILA}

Demokrasi adalah suatu system politik,yaitu system atau tatanan hidup bersama dalam bernegera,menurut filosof klasik(Plato,Aristoteles,Sokrates) system ini termasuk system yang tidak ideal di karenakan keputusan ada di tangan rakyat dan juga system ini mengedepankan sebuah kebebasan,sehingga di khawatirkan akan terjadi dampak yang merugikan seperti orasi rakyat yang besar-besaran,penindasan terhadap golongan yang minorotas karena sistem ini adalah bentuk pemerintahan yang mayoritas sebagai contoh rakyat mengambil alih sistem saat pilkada,tetapi sistem ini bias menjadi ideal jika supremasi hukum yang di bentuk di suatu Negara di tegakkan sehingga kehidupan warganya menjadi tentram dan damai.

Demokrasi Pancasila itu adalah Demokrasi yang bersifat gotong royong,kekeluargaan dan musyawarah,sehingga dalam praktiknya pula para pendiri bangsa ini (Soerkarno,Moh. Hatta,Yamin,Soepomo,dll) mendirikan Negara ini dengan cara bermusyawarah bukan karena keinginan sendiri dan keinginan satu kelompok tertetntu.Tetapi Demokrasi Pancasila saat ini 
mengapa sangat jauh dari nilai-nilai Pancasila tersebut yang seharusnya demokrasi tersebut berifat plurel,kaya dan bermakna tetapi saat ini masyarakat Indonesia jika mengemukakan orasinya selalu di warnai kekacauan selai itu demokrasi hanya alat yang di gunakan sebagai politikus untuk memperkaya diri sendiri,mengatas namakan kepentingan rakyat demi kepentingan diri sendiri,bukannya untuk melayani rakyat dengan seadil-adilnya tetapi malah mempergunakan amanatnya untuk memenuhi kebutuhan pribadinya,apakah mereka yang duduk di kursi-kursi dewan jika sudah membuka sebuah rapat akan menyebabkan kesejahteraan rakyatnya meningkat?mempermudah pelayanan rakyat untuk mengurus berbagai administrasi untuk kebutuhannya(misalnya:administrasi jaminan kesehatan)?,apakah pengangguran di Negara ini sudah turun signifikan?,menurut pandangan rakyat umum walaupun mereka melakukan rapat beribu-ribu kali tidak akan ada efek yang langsung bisa di rasakan rakyat dan bisa mebuat hidupnya lebih terjamin,banyak sekali korupsi yang terjadi di Negara ini yang membuat miris hati rakyat,seperti yang terjadi tidak lama ini bahwa di kota Malang ada 30 anggota DPRD lebih yang menjadi tersangka atas hasil korupsi yang dilakukan,itu salah satu contoh kebodohan yang terjadi di Negara ini,apa bedanya dengan orang yang mencuri sepasang sandal di suatu tempat,bahkan lebih tersiksa hidupnya yang mencuri sandal tersebut dari pada oknum yang berkorupsi,sebagai contoh jika didalam sel sang pencuri sandal harus di tahan di ruang sel yang penuh sesak,sedangkan yang oknum korupsi walaupun si penjara tetapi dia masih merasakan kemulyaan dengan ruang penjara yang lengkap dan jauh lebih nyaman bahkan ada juga yang ber AC dan memiliki kulkas pribadi dan TV flat,apakah itu yang di namakan keadilan yang di susun dalam pancasila di sila keadilan bagi seluruh rakyat Indonesia?.

Para pendiri Negara ini sudah susah payah membangun pondasi yang kuat,membangun karakter dari bangsa ini,dan menyusun undang-undang sebagai panutan yang harus di terapkan dalam hidup bernegara tetapi mengapa saat ini banyak sekali borok dari Negara ini yang terusterusan terjadi dan bahkan belum selesai walaupun kita sudah merdeka selama 73 tahun,seperti yang terjadi pada saat ini.

Di dalam demokrasi pancasila juga terdapat nilai-nilai pancasila yang mana nilai tersebut seharusnya melekat di dalam jiwa dan raga para masyarakat Indonesia,misalnya saja sila persatuan Indonesia,di dalam pemilu saat ini terdapat bnayak sekali guncangan yang terjadi dan meneybabkan perpecahan antar anggota kelompok demi mengunggulkan pasangan calonnya. 


\section{PRAKTIK PEMILU}

Pemilu adalah suatu hal yang utama dimana kedaulatan rakyat yang merupakan salah satu objek sistem demokrasi mempunyai pengaruh besar terhadap arah perjalanan negaranya ke depan,di dalam pemilu pula para masyarakat dapat melihat visi serta misi para calon yang maju yang akan di buat acuan untuk mengetahui apa saja yang akan di lakukan calon-calon tersebut kepada arah perkembangan Negara atau wilayahnya kedepan,pemilihan umum adalah suatu keharusan yang harus di lakukan jika Negara tersebut menyatak system kenegaraannya yang demokrasi,walau begitu pemilu dan demokrasi tidaklah sama,domokrasi adalah suatu system sedangkan pemilu adalah alat yang di gunakan untuk mendapatkan hasil yang terbaik yang bersifat LUBERJUDIL,yang merupakan singkatan dari:

- Langsung yang berarti pemilu harus di berikan suaranya secara langsung oleh masyarakat yang memenuhi syart-syarat mengikuti pemilu,tidak boleh di wakilkan.

- Umum yang berarti harus di ikuti oleh segenap warga bangsa Indonesia tanpa membedakan Ras,Suku,Agama,Jenis kelamin,dan juga Statusnya

- Bebas yang berarti pemilih di berikan kebebasan dalam memilih calon sesuai hati nuraninya tanpa di paksa dan tanpa tekanan apapun

- Rahasia yang berarti suara yang di pilih oleh peserta pemilu itu bersifat rahasia,hanya si pemilih yang berhak tau

- Jujur yang berarti dalam penghitungan suara para pihak panitia harus jujur sehingga hasil yang di raih adalah hasil suara yang $\mathrm{SAH}$

- Adil yang berarti bahwa antara pihak panitia pemilu dan pihak anggota harus berlaku adil dalam memberikan kesempatan untuk menyalurkan suaranya dan bagi peserta harus bersikap tidak memberikan suara yang golput

Tetapi tidak semua pemilihan itu bersifat demokrastis,pemilihan yang demokrasi harus bersifat kompetitif,berkala,luas,dan definitive,setidaknya ada empat fungsi utama pemilu yakni:

1. Pembentukan legitimasi penguasa dan pemerintahan

2. Pembentukan perwakilan politik

3. Sirkulasi elit politik

4. Pendidikan politik 
Selain pemilu mempunyai sifat yang terikat tersebut dan fungsi yang utama pemilu juga memiliki tujuan yang mutlak yang menyebabkan pemilu merupakan suatu proses yang sangat penting bagi Negara dengan system demokrasi,berikut tujuan di laksanakannya pemilu:

1. Terjadinya peralihan pemerintahan yang adil dan legitimasi

2. Melaksanakan kedaulatan rakyat yang mana rakyat merupakan pemotor system demokrasi

3. Melaksanakan hak asasi warganegaranya

Saat ini yang terjadi di Indonesia adalah pemilihan presiden dan anggota DPR,banyak sekali kubu yang saling menjatuhkan demi mendapatkan tempat di hati rakyat dan tentunya kursi di kantor DPR dan kursi sebagai presiden dan wakil presiden,bahkan kemarin publik juga di hebohkan lagi dengan skandal seorang oknum dari salah satu anggota parpol yang mengusung salah satu capres,dan ada lagi salah satu kebijakan yang dibuat oleh seorang presiden di publis dengan menyebutkan kata-kata "apakah ini benar-benar suatu kebijakan atau hanya untuk salah satu cara berkampanye?"oleh salah satu stasiun televisi swasta,apakah ini yang di inginkan para pendiri bangsa dan mencerminkan suatu demokrasi Pancasila?

Pemilu yang di langsungkan sejak masa orde lama sampai saat ini menurut saya sudah cukup baik mengingat Negara kita Negara yang demokratis,tetapi dalam prakteknya saat ini mengapa selalu di bumbui dengan hal yang bernuansa SARA,misalnya terdapat praktik money polytic yang selalu terjadi pada saat mendekati pemilu dan penyebaran berita hoax seperti yang saya paparkan di atas tadi,bagi masyarakat hal ini akan membuat ketidaknyamanan maka yang terjadi jika dalam praktiknya menggunakan cara money politik hasilnya para petinggi Negara akan banyak yang akan berkorupsi,sekarang ini hasil pemilu sebagian besar bukan dari hati nuraninya sendiri tetapi berdasarkan "saya memilih orang yang member saya uang yang paling banyak",selain itu di gembar gembornya janji-janji yang sebagian besar tidak terwujud jika sudah benar-benar terpilih,karena pada saat ini pada dasarnya masyarakat umum hanya sebagai alat dan bahan untuk mencari pekerjaan dan untuk mungurus kepentingan diri sendiri bagi politikus-politikus yang elit,sungguh situasi yang sangat-sangat memperhatinkan bagi Negara kita yang terkenal dengan Negara terbesar di dunia dengan beragam jumlah suku,budaya,flora,fauna,serta pemandangan alam yang sungguh indah yang orang asing bilang 
Indonesia adalah surga yang terletak di bumi,Negara yang berpotensi bisa menyaingi Amerika harus berjalan pelan untuk bisa berkembang karena ulah oknum-oknum pemimpin rakyat yang tidak mempunya hati ibu pertiwi.

\section{IMBAS KAMPANYE DENGAN MONEY POLYTIC}

Hal ini akan mempengaruhi kinerja banyak pihak seperti ketidak stabilan berpolitik,ketidak stabilan dalam ekonomi negara yang berimbas pada hasil jual beli pasar dalam negri,ketidak stabilan dalam pertahanan yang berimbas pada kesediaan alusista pertahanan negara,Para investorpun juga akan berpikir dua kali jika ingin berinvestasi di Negara kita dan akan menyebabkan bertambahnya pengangguran dan mempengaruhi bertambahnya presentase kemiskinan,jika mau membuka usaha modal yang di butuhkan tentu juga akan besar karena imbas dari kenaikan dolar terhadap rupiah yang berubah-ubah dan melonjak signifikan,biaya sekolahpun juga semakin mahal serta dirasa kebijakan yang di keluarkan bersifat menguntungkan sebelah pihak dalam hal kecil pajak yang semakin meningkat tanpa di berengi dengan perbaikan invastruktur yang memadai masih ada beberapa titik di suatu daerah yang harus di perbaiki tetapi tidak segera di perbaiki,padahal semboyan pajak adalah "hasil pajak yang anda bayarkan untuk kesejahteraan rakyat bersama".

Semua kejadian ini tidak akan terjadi bila kaum politikus dan masyarkat Indonesia ingat dan paham pada dasar negara atau weltanschauung Negara kita didirikan seperti yang sudah di rumuskan,dipikirkan,dibahas dan diolah di sidang BPUPKI oleh Soekarno,Moh.Hatta,Yamin,Soepomo,jika kita mendirikan bangsa ini bukan untuk sesaat tetapi sekali berdiri maka akan tetap berdiri selamanya,Negara ini bukan untuk siapa-siapa tetapi Negara Indonesia didirikan untuk semua rakyat Indonesia.

Kembali lagi pada unsur dasar Negara kita yaitu gotong royong,maka bentuklah dan dirikanlah Negara kita berdasarkan asas gotong royong,semua permasalahan di rembukan dalam sidang yang transparan dan aspirasi rakyat didengarkan betul oleh anggota-anggota DPR,mengedepankan kepentingan bersama dari pada kepentingan pribadi,perbedaan pendapat dan kontroversi jangan di pakai untuk menjatuhkan satu sama lain tapi buatlah itu untuk hal yang bisa di hargai dan bersainglah dengan sehat,sejauh ini negara kita terdiri dari 2 kubu yaitu kubu partai yang berdasarkan sifat agama dan kubu partai yang berdasarkan sifat 
nasionalisme,bagaimana cara kita bisa mengkombinasikan antar dua kubu tersebut untuk membangun Negara kita,di dalam demokrasi pancasila tidak memberatkan salah satu kubu tersebut karena Negara Indonesia di dirikan untuk semua rakyat Indonesia dan perbedaan itu jangan sampai di buat untuk saling menjatuhkan.

Jika dalam demokrasi kita menggunakan cara musyawarah yang mufakat maka akan menghasilkan pemimpin yang ideal,yang bisa benar-benar merakyat dan jauh dari sifat korupsi,jika demokrasi berdasarkan hasil voting maka di dalam lingkup masyarakat akan timbul sifat kecemburan sosial karena akan ada pihak yang minoritas dan akan terus berlangsung sampai pemilu berikutnya dan belum tentu itu melahirkan pemimpin yang benar-benar bijaksana dalam mengambil keputusan. 


\section{DAFTAR PUSTAKA}

https://id.wikipedia.org/wiki/Pemilihan_umum_di_Indonesia

http://diy.kpu.go.id/web/2016/12/19/pengertian-fungsi-dan-sistem-pemilihan-umum/

http://manado.tribunnews.com/2018/06/22/menciptakan-pemilu-indonesia-berlandaskan-

demokrasi-pancasila-yang-berbasis-pelayanan-publik

Dewantara, Agustinus W. 2017. Diskursus Pancasila Dewasa Ini. D.I Yogyakarta: PT Kanisius.

Dewantara, A. (2017). Alangkah Hebatnya Negara Gotong Royong (Indonesia dalam Kacamata Soekarno). 